\title{
MORPHO-PHYSIOLOGICAL ASSESSMENT OF OIL PALM (Elaeis guineensis Jacq.) SEEDLINGS EXPOSED TO SIMULATED DROUGHT CONDITIONS
}

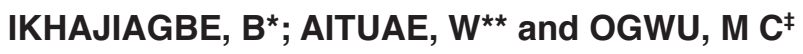

\begin{abstract}
Elaeis guineensis Jacq. (oil palm) production is threatened by drought due to climate change and anthropogenic deforestation. This study aims to understand how drought conditions contribute to changes in foliar nitrate-nitrogen concentration as well as the effects on the growth and development of oil palm seedlings. Seventy oil palm seedlings were maintained in a screen house and subjected to simulated drought conditions. There was a significant reduction in the number of leaves with increased drought exposure from 10 to four per plant. Oil palm leaves exposed to higher drought levels had less broad leaves, with leaf area ranging from 133.25-172.22 $\mathrm{cm}^{2}$ compared to the control $\left(383.73 \mathrm{~cm}^{2}\right)$. The foliar yield per plant was low in plants exposed to extreme drought condition $(2.27 \mathrm{~g})$, compared to $71.98 \mathrm{~g}$ in the control. Moreover, total drought-exposed oil palm seedlings had the highest concentration of nitrate-nitrogen. E. guineensis exposed to no-drought conditions had more roots (18 roots) than those exposed to total or partial drought (6-10 roots per plant). Overall, there was a decrease in height, leaf area and the number of leaves for most of the seedlings exposed to drought condition, which might be detrimental to their photosynthetic ability and growth.
\end{abstract}

Keywords: climate change effects, drought, foliar nitrogen, oil palm (Elaeis guineensis).

Received: 13 May 2020; Accepted: 17 February 2021; Published online: 4 May 2021.

\section{INTRODUCTION}

Oil palm (Elaeis guineensis Jacq.), is a monocotyledonous tropical palm tree, which belongs to the family Arecaceae and is believed to have originated in West Africa (Poku, 2002). It is the major source of edible and industrial oil in west, east and central parts of Africa and Madagascar. Elaeis guineensis is also domesticated in Sri Lanka,

\footnotetext{
Department of Plant Biology and Biotechnology, Faculty of Life Sciences, University of Benin, Ugbowo, Benin City PMB 1154, Nigeria.

** Physiology Division, Nigeria Institute for Oil Palm Research, Benin City, Nigeria.

₹ School of Biosciences and Veterinary Medicine, University of Camerino - Center for Floristic Research of the Apennine, Gran Sasso and Monti Della Laga National Park, San Colombo, 67021 Barisciano, L'Aquila, Italy. E-mail: matthew.ogwu@uniben.edu
}

Indonesia, Malaysia, Madagascar, Central America, along with many other island states in the Indian and Pacific Oceans. It is a close relative of the American oil palm (Elaeis oleifera [Kunth.] Cortes) and a distant relative of maripa palm (Attalea maripa [Aubl.] Mart.) found in the Caribbean (Hormaza et al., 2012). Human use of oil palms dates as far back as 5000 years in West Africa. Three cultivars of oil palm are common in Nigeria; namely Dura, Pisifera and Tenera (FAO, 2002; Okolo et al., 2019). The preferred variety among oil palm farmers in Nigeria is the hybrid cultivar, Tenera; which is a crossbreed of Dura (female) and Pisifera (male). Tenera seedlings are produced by the Nigeria Institute for Oil Palm Research (NIFOR) and largely used in extension works to promote oil palm cultivation (Iankova et al., 2016). In terms of comparison, the fruit of the Tenera contains 25\% oil (by weight), whereas it is $18 \%$ in Dura. Oil palm is common in Edo State, 
Nigeria where climate change events are becoming more frequent (Ogwu et al., 2014; Ogwu, 2019).

Uptake of nutrients is low during the first year in oil palm but increases steeply between year one and three (when harvesting commences) and stabilises around years five to six (Woittiez et al., 2017). Early applications of fertiliser, better planting material and more rigid culling have led to a dramatic increase in early yields in the third to sixth year after planting. Nitrogen, which mostly enters the plant as soluble nitrate ion, is a building block for tissue growth. Nitrogen is an integral part of most essential components including in chlorophyll and nucleic acids. Without nitrogen, there might be limited to no growth and yield. Nitrogen deficiency first shows up as discolouration of young oil palm fronds, which lose their healthy dark green colour and turn yellow (chlorosis). Nitrogen deficiency is caused by some factors including poor drainage and waterlogged soil; inherently infertile soils exhausted by previous agricultural activities, excessive competition from weeds (Hartley, 1988; Lai et al., 2019). In regions without a significant drop in rainfall, yields of over $25 \mathrm{t}$ of fresh fruit bunches (FFB) per hectare have been achieved in the second year of harvesting. On the other hand, drought stress results when water loss from the plant exceeds the ability of roots to absorb water and when the plant's water content is reduced enough to interfere with normal plant processes. Water is a universal solvent needed by plants to grow and is a major constituent of plant cells, without which, photosynthesis and consequently, growth processes may be hampered (Carr, 2011; Safitri et al., 2019).

This study aims to understand how drought conditions contribute to changes in foliar nitratenitrogen concentration as well as the effects on the growth and development of oil palm. The combined use of morphology and other traits to characterise plant germplasm is increasingly commonplace (Osawaru et al., 2013; 2014a; b). Drought stress may take time to become visible in plants and depends on the water holding capacity (WHC) of the soil, environmental conditions, stage of plant growth and plant species. Moreover, poorly established plants are more susceptible to drought stress because of the limited root system (low root-shoot ratio). During drought conditions, there is a shortage of water for plant use. Hence, given the obvious challenges posed by recent trends in climate change, it is pertinent to assess drought stress in oil palm seedlings.

\section{MATERIALS AND METHODS}

\section{Plant Materials and Growth Conditions}

Seventy palm samples, all of which were six months old where selected randomly from a pool of oil palm nursery at NIFOR, Benin City, Nigeria. The oil palm seedlings were held in black polyethene nursery bags and maintained in a screen house to shield the palms from rainfall. It is in the screen house that different water treatments were applied to the oil palm seedlings. The experiment was initiated in July 2018, but the application of treatments started in August 2018, which was enough time for the oil palm seedlings to get acclimatised to the screen house. Measurements of experimental parameters took place six months after sowing.

\section{Collection of Topsoil Used in the Study}

Topsoil $(0-15 \mathrm{~cm})$ was collected from NIFOR and pooled to obtain composite samples. The soil was sun-dried to constant weight. Thereafter $7.50 \mathrm{~kg}$ was measured each into perforated nursery bags. A total of 70 bags were arranged in the screen house for the experiment.

\section{Water Holding Capacity (WHC) of the Soil}

The experiment relied on the restricted application of water and the WHC of the soil was determined before commencing the experimental procedures. About $1.00 \mathrm{~kg}$ of sun-dried soil was placed in a funnel initially lined with Whatman's filter paper (A). Water was poured unto it to completely saturate the soil. This was left overnight in a darkroom. The next morning, the weight of the saturated soil was taken (B) and the difference (B-A) was expressed in $\mathrm{ml}$ per $\mathrm{kg}$. The WHC of the soil was determined to be $480 \mathrm{ml} \mathrm{kg}^{-1}$. This amounted to $3600 \mathrm{ml}$ per nursery bag.

\section{Simulation of Drought}

The drought conditions for the experiment was a factor of the WHC. There were six levels comprising of control, total drought, $0.05 \% \mathrm{WHC}, 0.1 \% \mathrm{WHC}$, $0.5 \% \mathrm{WHC}, 1 \% \mathrm{WHC}$ and 5\% WHC (Table 1).

\section{Application of Treatment}

Initially, the entire nursery bags received $3600 \mathrm{ml}$ of water, which represented the WHC of the entire $7.50 \mathrm{~kg}$ soil. Thereafter, the oil palm seedlings were transplanted and left in the screen house for two weeks. Subsequently, the seedlings were divided into seven groups, comprising 10 per group and randomised within the experimental block. Each group received the designated amount of water as presented in Table 1.

\section{Determination of Plant Growth Characteristics}

Some plant growth characteristics including the number of leaves as well as dry weight of the 
total number of leaves (hereafter referred to as foliar yield). Number of roots were also physically counted. In the experiment, the prominent roots were defined as those roots that were significantly larger and longer than the other roots. The lengths of these prominent roots were determined. Similar to foliar yield, root yield per plant was calculated as dry weight of all physically removed roots.

\section{Determination of Nitrate-Nitrogen}

This was carried out according to Smith (1974) and summarised here - test plant was oven-dried at $65^{\circ} \mathrm{C}$ for $24 \mathrm{hr}$ and then ground to 40 -mesh sized powder. The ground sample was re-dried in an oven at $70^{\circ} \mathrm{C}$. A measure of $100 \mathrm{mg}$ of ground sample was suspended in deionised water and incubated at $45^{\circ} \mathrm{C}$ for $1 \mathrm{hr}$. The incubated suspension was then mixed and centrifuged at $5000 \mathrm{xg}$ for $15 \mathrm{~min}$ to sediment tissue residues. The supernatant was decanted and kept for analysis.

\section{Preparation of Stock Nitrate Solution}

Potassium trinitrate $(\mathrm{V})\left(\mathrm{KNO}_{3}\right)$ was oven dried for $24 \mathrm{hr}$ at $105^{\circ} \mathrm{C}$ and then $1.63 \mathrm{~g}$ of the dried salt was weighed into $250 \mathrm{ml}$ flask and dissolved with distilled water. The solution was transferred into 1-litre flask made to the mark with distilled water to obtain 1000 ppm of stock $\mathrm{KNO}_{3}$ solution.

\section{Preparation of Standard Nitrate Solution}

Using a $100 \mathrm{ml}$ measuring cylinder, $50 \mathrm{ml}$ of the stock solution was measured into $500 \mathrm{ml}$ flask and made to the mark with water. This was carefully swirled to mix to obtain $100 \mathrm{mg}$ litre $^{-1}$ of the stock. From the $100 \mathrm{mg}$ litre $^{-1}$ standards concentrations of 80-10 mg litre ${ }^{-1}$ was prepared by serial dilution.

\section{Preparation of $2 \mathrm{~N}$ Solution of $\mathrm{NaOH}$}

Exactly $40 \mathrm{~g}$ of $\mathrm{NaOH}$ pellets were introduced into a $250 \mathrm{ml}$ beaker and dissolved with distilled water. The solution obtained was transferred into a $500 \mathrm{ml}$ flask and made up to the mark.

\section{Preparation of Salicylic Acid Solution}

Five grams of salicylic acid was dissolved in concentrated sulphuric acid $\left(\mathrm{H}_{2} \mathrm{SO}_{4}\right)$ and diluted to $100 \mathrm{ml}$ with the same acid. The solution obtained was stored in amber bottles.

\section{Calibration and Estimation of Nitrate- $\mathrm{N}$ in Plant} Tissue

Aliquots $(0.1 \mathrm{ml})$ of working standards solution in $30 \mathrm{ml}$ tube were mixed thoroughly with 0.4 $\mathrm{ml}$ salicylic acid solution. After $20 \mathrm{~min}$ at room temperature, $9.5 \mathrm{ml} 2 \mathrm{~N}$ sodium hydroxide $(\mathrm{NaOH})$ solution was slowly added to obtain 0.1-1.0 mg litre $^{-1} \mathrm{NO}_{3}-\mathrm{N}$ solutions. The plant extract was analysed for Nitrate- $\mathrm{N}$ by mixing $5 \mathrm{~g}$ plant extract, $0.8 \mathrm{ml}$ concentrated $\mathrm{H}_{2} \mathrm{SO}_{4}, 19 \mathrm{ml}$ of $\mathrm{NaOH}$ and 0.4 $\mathrm{ml}$ of salicylic acid solution. A similar mixture of the plant extract (without salicylic acid) was used as blank. The nitrosalicylic acid complex formed was read at maximum absorption of $412 \mathrm{~nm}$ using a spectrophotometer.

For this determination, seven different water rates were applied to oil palm seedlings; control, total drought, $0.05 \% \mathrm{WHC}, 0.1 \% \mathrm{WHC}, 0.5 \%$ WHC, 1\% WHC and 5\% WHC. Each treatment was replicated 10 times namely; A, B, C, D, E, F, G, H, I, J, culminating in 70 experimental units. The experimental units were then laid out in the completely randomised design in the NIFOR screen house.

\section{STATISTICAL ANALYSIS}

Data obtained from the study were analysed using statistical package for social sciences (SPSS) statistical software version 21. Results were presented as the mean of 10 replicates and separated at $95 \%$ confidence interval.

TABLE 1. EXPERIMENTAL TREATMENTS TO SIMULATE DROUGHT CONDITIONS

\begin{tabular}{lll}
\hline Treatments & Treatment factor per $7.5 \mathbf{~ k g}$ soil & Quantity of water applied to soil (7.5 kg) per week \\
\hline Control & Soil was watered normally & Frequent soil wetting as soon as soil moisture was reduced \\
Total drought & No water applied at all & $0.36 \mathrm{ml}$ applied to soil weekly \\
$0.05 \% \mathrm{WHC}$ & $0.005 \times 3600=1.8 \mathrm{ml}$ & $1.8 \mathrm{ml}$ applied to soil on a weekly basis \\
$0.1 \% \mathrm{WHC}$ & $0.0001 \times 3600=3.6 \mathrm{ml}$ & $23.6 \mathrm{ml}$ applied to soil on a weekly basis \\
$0.5 \% \mathrm{WHC}$ & $0.0001 \times 3600=18.0 \mathrm{ml}$. & $18.0 \mathrm{ml}$ applied to soil on a weekly basis \\
$1 \% \mathrm{WHC}$ & $0.0001 \times 3600=36.0 \mathrm{ml}$ & $36.0 \mathrm{ml}$ applied to soil on a weekly basis \\
$5 \% \mathrm{WHC}$ & $0.0001 \times 3600=180.0 \mathrm{ml}$ & $180.0 \mathrm{ml}$ applied to soil on a weekly basis \\
\hline
\end{tabular}

Note: WHC - water holding capacity. 


\section{RESULTS AND DISCUSSION}

The present study explored the assimilation of nitrogen in oil palm seedlings exposed to drought stress. Some morphological parameters of the palm seedlings at six months after sowing are presented in Table 2. Results showed a significant reduction in the number of leaves with increased drought exposure from 10 to four per plant. Similarly, leaves that were exposed to higher drought levels had less broad leaves, with leaf area ranging from $133.25-172.22 \mathrm{~cm}^{2}$, compared to the control with a leaf area of $383.73 \mathrm{~cm}^{2}$. The foliar yield per plant was significantly low in the plant with the total drought treatment $(2.27 \mathrm{~g})$, compared to $71.98 \mathrm{~g}$ in the control. Altogether, these results suggest the importance of water supply in oil palm production as earlier suggested by Carr (2011). Moreover, this also supports the findings of Caliman and Southworth (1998), which highlighted the effects El Nino-induced droughts in oil palm cultivation region of Southeast Asia.

There was a general decrease in the height of most of the seedlings exposed to drought condition. It was observed that the height of oil palm seedlings at Week 4 was $31.10 \mathrm{~cm}$ and $36.40 \mathrm{~cm}$ at Week 16 in $\mathrm{T} 1$, which showed less than $15 \%$ increase in height compared to the control group. Height of seedling increased from $27.5 \mathrm{~cm}$ at Week 4 to 57.1 $\mathrm{cm}$ in control, which showed over 50\% increase with respect height of seedlings. The difference is clearly because the control oil palm seedlings were not subjected to physiological (and other) stress and therefore performed normal metabolic functions needed for its growth and development. In the same way, Gupta et al. (2001) also observed a slow progression in height of their test plants, which they attributed to low water potential elicited by drought condition. Further, this may have raised the osmotic potential in the test plant, thus, prompting the expression of genes that code for traits essential for survival without a significant increase in height (Delperee et al., 2003; Zgallai et al., 2006). Neilson et al. (2015) used advanced high-throughput screening platforms equipped with an automated irrigation system to measure a wide range of morpho-physiological variables in a large number of genotypes of cereal crops to support their view that plants have the capacity to down-regulate genes for certain metabolic activities under drought stress. The age of the oil palm seedlings and the duration of the drought period are important factors in the present study. However, plants can respond properly to drought stress with enhanced growth-promoting hormones like auxin (Mshelmbula et al., 2015; Ogwu et al., 2015, Ogwu, 2018).

The number of necrotic leaves on oil palm seedlings at six months after planting are presented in Table 3. The effects of drought was noticed in all the test plants as leaf necrosis began to appear after four weeks and progressed over time. There were 4.80 necrotic leaves at Week 4 in the total droughtexposed oil palm seedlings and increased to 5.08 by Week 14. In oil palm seedlings exposed to soils with $0.1 \%$ WHC, the number of necrotic leaves were 4.85 at Week 4 and 5.03 at Week 14, whereas the number of necrotic leaves in the control group remains significantly negligible compared to the test plants subjected to drought stress. Observably, although oil palm seedlings exposed to soils with $0.5 \%$ WHC showed similar evidence of drought stress with evidence of necrosis like other test plants, the number of necrotic leaves in the plant had remained fairly the same throughout the study. The work of Ikhajiagbe and Anoliefo (2011) suggest that plant tolerance to drought can be enhanced by using soil amendments.

TABLE 2. MORPHOLOGICAL ASSESSMENT OF DROUGHT-EXPOSED OIL PALM SEEDLINGS AT SIX MONTHS AFTER SOWING

\begin{tabular}{|c|c|c|c|c|c|c|}
\hline Treatments & $\begin{array}{l}\text { Plant height } \\
\quad(\mathrm{cm})\end{array}$ & ${ }^{*}$ No. of leaves & $\begin{array}{l}\text { Leaf area } \\
\qquad\left(\mathrm{cm}^{2}\right)\end{array}$ & $\begin{array}{l}\text { Foliar yield/ plant } \\
\text { (g) }\end{array}$ & $\begin{array}{c}\text { Percentage } \\
\text { senescence }(\%)\end{array}$ & $\begin{array}{l}\text { Stem girth } \\
(\mathrm{cm})\end{array}$ \\
\hline Total drought & $35.8 \pm 2.3^{\mathrm{a}}$ & $5 \pm 2^{\mathrm{a}}$ & $166.27 \pm 45.32^{\mathrm{a}}$ & $2.27 \pm 1.08^{\mathrm{a}}$ & $25.36 \pm 9.02^{\mathrm{ab}}$ & $4.40 \pm 0.92^{\mathrm{a}}$ \\
\hline $0.05 \% \mathrm{WHC}$ & $33.4 \pm 3.4^{\mathrm{a}}$ & $6 \pm 2^{a}$ & $133.25 \pm 52.14^{\mathrm{a}}$ & $4.37 \pm 1.65^{\mathrm{a}}$ & $43.39 \pm 11.37^{b}$ & $4.58 \pm 1.01^{\mathrm{a}}$ \\
\hline $0.1 \% \mathrm{WHC}$ & $36.4 \pm 2.7^{\mathrm{a}}$ & $6 \pm 2^{\mathrm{a}}$ & $142.76 \pm 27.22^{\mathrm{a}}$ & $5.46 \pm 2.01^{\mathrm{a}}$ & $22.21 \pm 9.11^{\mathrm{ab}}$ & $4.75 \pm 0.65^{\mathrm{a}}$ \\
\hline $0.5 \% \mathrm{WHC}$ & $36.5 \pm 3.2^{\mathrm{a}}$ & $4 \pm 2^{\mathrm{a}}$ & $160.76 \pm 75.06^{\mathrm{a}}$ & $4.77 \pm 1.88^{\mathrm{a}}$ & $33.37 \pm 8.02^{\mathrm{b}}$ & $4.03 \pm 0.42^{\mathrm{a}}$ \\
\hline $1 \% \mathrm{WHC}$ & $34.4 \pm 4.1^{\mathrm{a}}$ & $5 \pm 3^{\mathrm{a}}$ & $152.42 \pm 66.93^{\mathrm{a}}$ & $5.88 \pm 2.66^{\mathrm{a}}$ & $37.52 \pm 9.02^{\mathrm{b}}$ & $4.20 \pm 0.73^{\mathrm{a}}$ \\
\hline $5 \% \mathrm{WHC}$ & $43.2 \pm 2.9^{\mathrm{b}}$ & $7 \pm 2^{\mathrm{ab}}$ & $172.22 \pm 55.11^{\mathrm{a}}$ & $20.13 \pm 8.42^{b}$ & $11.10 \pm 7.14^{\mathrm{a}}$ & $5.63 \pm 1.12^{\mathrm{a}}$ \\
\hline Control & $49.7 \pm 2.3^{c}$ & $10 \pm 3^{b}$ & $383.73 \pm 85.73^{b}$ & $71.98 \pm 19.02^{c}$ & $0.00^{c}$ & $9.30 \pm 1.82^{\mathrm{b}}$ \\
\hline p-value & $<0.001$ & 0.034 & $<0.001$ & $<0.001$ & $<0.001$ & $<0.001$ \\
\hline
\end{tabular}

Note: *Means and standard error have been provided to the nearest whole number. The concentrations of water applied to soil were based on soil's initial water holding capacity. Values on same column with similar alphabetic superscripts. are not significantly different from one another $(\mathrm{p}>0.05)$. FL/Plant = No. of foraged leaves/plant; PFC - percentage foliar chlorosis. WHC - water holding capacity. 
Leaf area is affected during drought stress conditions in plants, as plants tend to reduce the possibility of losing more water in addition to the prevalent condition. There were general increases in the leaf areas in all the experimental plants irrespective of the treatment. Nonetheless, the increase in leaf area was lower in all the oil palm seedlings subjected to drought conditions compared to that of control group. This could probably be due to the restrained metabolic processes necessary to promote leaf enlargement in the plant and also reduce evapotranspiration, which could hasten the death of drought-stressed plant through acute dehydration (Parker and Pallardy, 1985; Puértolas et al., 2017). As the stress condition intensified, the plant may resort to drastic steps to increase its chances of survival under the prevailing unsupportive environment and this may be effective by the production of metabolites that cause leaf senescence resulting from stress and not from age. This explains the reduction in the number of leaves observed in oil palm seedlings after exposure to drought stress in the present study (Table 3). This view is in line with the outcome of previous investigations including those of Kafi and Mahdavi-Damghani (1999); Kabiri (2010); Kavar et al. (2007).

Nitrate concentration was assayed in oil palm seedlings during the present study and results showed that total drought-exposed oil palm seedlings had the highest concentration of nitratenitrogen (Table 4). Nitrate concentration was 3.17 $\mathrm{mg} \mathrm{kg}^{-1}$ dry weight (DW) of oil palm seedling in the total drought-exposed oil palm seedlings whereas it was $0.88 \mathrm{mg} \mathrm{kg}^{-1} \mathrm{DW}$ in the oil palm seedlings exposed to $0.5 \%$ WHC and it was $1.64 \mathrm{k} \mathrm{kg}^{-1} \mathrm{DW}$ and $1.62 \mathrm{mg} \mathrm{kg}^{-1} \mathrm{DW}$ in oil palm seedlings exposed to $0.1 \% \mathrm{WHC}$ and $1 \% \mathrm{WHC}$ respectively. Symptoms of drought in oil palm include general paling and stiffening of the pinnae, which lose their glossy lustre. The report of Al-Amin et al. (2011) suggests that drought lower the yield of FFB in oil palm up to $26.30 \%$. The decline of oil palm yield is a direct effect of inhibition of the photosynthetic rate of oil palm (Jafaar and Ibrahim, 2012; Russell et al., 2017). Increasing nitrogen utilisation in the face of environmental stress can also improve plant performance (Ikhajiagbe et al., 2020).

TABLE 3. NUMBER OF LEAVES WITH NECROTIC LESIONS OF DROUGHT-EXPOSED OIL PALM SEEDLINGS AT SIX MONTHS AFTER SOWING

\begin{tabular}{|c|c|c|c|c|c|c|c|}
\hline \multicolumn{8}{|c|}{ Weeks after transplanting } \\
\hline Treatments & 4 & 6 & 8 & 10 & 12 & 14 & 16 \\
\hline Total drought & $4.8 \pm 0.44^{\mathrm{ab}}$ & $5.45 \pm 0.98^{\mathrm{a}}$ & $5.75 \pm 0.83^{\mathrm{a}}$ & $5.70 \pm 0.93^{c}$ & $4.6 \pm 0.52^{\mathrm{a}}$ & $5.08 \pm 0.83^{\mathrm{a}}$ & $4.40 \pm 0.52^{\mathrm{a}}$ \\
\hline $0.05 \% \mathrm{WHC}$ & $4.47 \pm 0.65^{\mathrm{a}}$ & $4.72 \pm 1.01^{\mathrm{a}}$ & $4.88 \pm 0.73^{\mathrm{a}}$ & $4.9 \pm 0.74^{\mathrm{bc}}$ & $4.1 \pm 0.99^{\mathrm{a}}$ & $4.75 \pm 1.22^{\mathrm{a}}$ & $4.58 \pm 0.73^{\mathrm{a}}$ \\
\hline $0.1 \% \mathrm{WHC}$ & $4.85 \pm 0.83^{\mathrm{ab}}$ & $5.25 \pm 0.93^{\mathrm{a}}$ & $5.58 \pm 1.06^{\mathrm{a}}$ & $5.23 \pm 0.41^{\mathrm{bc}}$ & $4.8 \pm 0.73^{\mathrm{a}}$ & $5.03 \pm 0.734^{\mathrm{a}}$ & $4.75 \pm 1.01^{\mathrm{a}}$ \\
\hline $0.5 \% \mathrm{WHC}$ & $4.8 \pm 0.81^{\mathrm{ab}}$ & $4.40 \pm 1.01^{\mathrm{a}}$ & $5.18 \pm 0.99^{a}$ & $4.35 \pm 0.44^{\mathrm{b}}$ & $5.6 \pm 1.04^{\mathrm{a}}$ & $4.60 \pm 1.42^{\mathrm{a}}$ & $4.03 \pm 0.55^{\mathrm{a}}$ \\
\hline $1 \% \mathrm{WHC}$ & $5.5 \pm 0.38^{b}$ & $4.67 \pm 0.85^{\mathrm{a}}$ & $5.28 \pm 0.75^{\mathrm{a}}$ & $4.68 \pm 0.39^{b}$ & $5.1 \pm 0.79^{\mathrm{a}}$ & $5.18 \pm 2.02^{\mathrm{a}}$ & $4.20 \pm 0.92^{\mathrm{a}}$ \\
\hline $5 \% \mathrm{WHC}$ & $5.2 \pm 0.42^{\mathrm{ab}}$ & $5.12 \pm 0.73^{\mathrm{a}}$ & $4.58 \pm 1.03^{\mathrm{a}}$ & $4.8^{\mathrm{b}} \pm 0.31^{\mathrm{c}}$ & $5.9 \pm 1.15^{\mathrm{a}}$ & $5.70 \pm 1.55^{\mathrm{a}}$ & $5.63 \pm 1.15^{a}$ \\
\hline Control & $1.1 \pm 0.33^{c}$ & $1.23 \pm 0.18^{c}$ & $1.32 \pm 0.78^{c}$ & $1.24 \pm 0.66^{\mathrm{a}}$ & $1.2 \pm 0.78^{\mathrm{b}}$ & $1.18 \pm 0.64^{\mathrm{b}}$ & $1.30 \pm 0.56^{\mathrm{b}}$ \\
\hline P-value & 0.323 & 0.415 & 0.776 & 0.004 & 0.004 & 0 & 0 \\
\hline F-value & 1.248 & 1.062 & 0.535 & 4.531 & 4.495 & 11.97 & 32.906 \\
\hline
\end{tabular}

Note: The concentrations of water applied to soil were based on soil's initial water holding capacity (WHC). Values on the same column with similar alphabetic superscripts do not differ from one another $(p>0.05)$.

TABLE 4. CONCENTRATION OF NITRATE IN THE LEAVES OF DROUGHTEXPOSED OIL PALM SEEDLINGS AT SIX MONTHS AFTER SOWING

\begin{tabular}{lc}
\hline Treatments & Foliar nitrate concentration $(\mathbf{m g} / \mathbf{k g}$ DW $)$ \\
\hline Total drought & $3.17 \pm 1.04^{\mathrm{b}}$ \\
$0.05 \% \mathrm{WHC}$ & $1.36 \pm 0.78^{\mathrm{ab}}$ \\
$0.1 \% \mathrm{WHC}$ & $1.64 \pm 0.65^{\mathrm{ab}}$ \\
$0.5 \% \mathrm{WHC}$ & $1.26 \pm 0.82^{\mathrm{ab}}$ \\
$1 \% \mathrm{WHC}$ & $1.62 \pm 0.79^{\mathrm{ab}}$ \\
$5 \%$ WHC & $0.88 \pm 0.23^{\mathrm{a}}$ \\
Control & $1.07 \pm 0.64^{\mathrm{a}}$ \\
F-value & $1.73 \times 10^{6}$ \\
P-value & $1.84 \times 10^{6}$ \\
\hline
\end{tabular}

Note: The concentrations of water applied to soil were based on soil's initial water holding capacity (WHC). Values on the same column with similar alphabetic superscripts are not significantly different from one another $(p>0.05)$. 
Below ground parameters of the test plants showed that plants exposed to non-drought conditions had significantly more roots (18 roots) than those exposed to total or partial drought (6-10 roots per plant) (Table 5). There were between two and four prominent roots across the experiment, irrespective of drought conditions. However, root yield per plant, which was determined in the study as the dried weight of entire roots obtained per plant, was higher in the control (11.46 g) than in the drought-exposed plants (3.50-6.53 g). The low stomatal conductance decreases the rate of carbon dioxide $\left(\mathrm{CO}_{2}\right)$ diffusion so that the photosynthetic activity of oil palm is inhibited (Henson and Harun, 2007). Other factors that inhibit the rate of photosynthesis in drought conditions are the relatively low water content (Fahramand et al., 2014; Zain et al., 2014), low chlorophyll $a / b$, and reduced nitrogen and phosphorus contents in leaf tissue of plants (Zlatev and Lindon, 2012; Ashraf and Harris, 2013).

Morphological description of drought-exposed oil palm seedlings at six months after sowing are presented in Table 6. Results showed that plants that were exposed to total drought showed dried-out leaves and most of them folded upwards. Leaves of the control plants were green, with no signs of chlorotic or necrosis; only two leaves showed signs of foliar scorching. During periods of drought, nutrient deficiency and changes in metabolism are common in oil palm (Silva et al., 2018). Our results support the recent findings by Corley et al. (2018) that the future of the oil palm industry will depend on the successful breeding of drought-resistant species.

\section{CONCLUSION}

In conclusion, drought stress leads to poor growth and development in oil palm seedlings, which may lower production in oil palm. Drought causes stomatal conductance of oil palm leaves to decline rapidly as more stomata close, which may also be detrimental to the photosynthetic ability and growth of the plant. Oil palm is very sensitive to drought and countries where products are greatest are highly vulnerable to this climate change effect. Therefore, if current trends are left unchecked, in a few decades climate change-induced drought might significantly affect the global output of oil palm. Agronomic approaches can be taken to reduce the sensitivity of oil palm to drought including planting drought-resistant varieties and adopting

TABLE 5. NUMBER OF ROOTS AND LENGTH OF PROMINENT ROOT OF DROUGHT-EXPOSED OIL PALM SEEDLINGS AT SIX MONTHS AFTER TRANSPLANTING

\begin{tabular}{|c|c|c|c|c|}
\hline Treatments & No of roots & ${ }^{*}$ No. of prominent roots & Length of prominent roots & Total root weight (g DW) \\
\hline Total drought & $10 \pm 3^{b}$ & $2 \pm 1^{\mathrm{a}}$ & $23.4 \pm 8.3^{c}$ & $3.504 \pm 1.032^{\mathrm{a}}$ \\
\hline $0.05 \% \mathrm{WHC}$ & $7 \pm 3^{\mathrm{b}}$ & $4+2^{a}$ & $27.1 \pm 7.1^{\mathrm{c}}$ & $3.195 \pm 1.109^{\mathrm{a}}$ \\
\hline $0.1 \% \mathrm{WHC}$ & $10 \pm 2^{\mathrm{b}}$ & $3 \pm 1^{\mathrm{a}}$ & $27.7 \pm 6.8^{c}$ & $3.054 \pm 1.047^{\mathrm{a}}$ \\
\hline $0.5 \% \mathrm{WHC}$ & $6 \pm 3^{b}$ & $2 \pm 1^{a}$ & $35.5 \pm 7.4^{\mathrm{bc}}$ & $4.832 \pm 0.092^{\mathrm{a}}$ \\
\hline $1 \% \mathrm{WHC}$ & $7 \pm 3^{b}$ & $3 \pm 1^{\mathrm{a}}$ & $24.4 \pm 9.3^{c}$ & $4.194 \pm 0.432^{\mathrm{a}}$ \\
\hline $5 \% \mathrm{WHC}$ & & $2 \pm 1^{\text {a }}$ & $70.5 \pm 11.1^{\mathrm{a}}$ & $6.532 \pm 0.509^{\mathrm{b}}$ \\
\hline Control & & $3 \pm 1^{a}$ & $57.5 \pm 9.4^{\mathrm{ab}}$ & $11.458 \pm 2.093^{c}$ \\
\hline $\mathrm{p}$-value & 0.002 & 0.643 & 0.015 & $<0.001$ \\
\hline
\end{tabular}

Note: *Means and standard error have been provided to the nearest whole number. The concentrations of water applied to soil were based on soil's initial water holding capacity (WHC). Values on the same column with similar alphabetic superscripts are not significantly different from one another $(\mathrm{p}>0.05)$.

TABLE 6. MORPHOLOGICAL DESCRIPTION OF DROUGHT-EXPOSED OIL PALM SEEDLINGS AT SIX MONTHS AFTER SOWING

\begin{tabular}{ll}
\hline \multicolumn{1}{c}{ Treatments } & \multicolumn{1}{c}{ Morphological description } \\
\hline Total drought & Leaves were totally dry and most of them were folded upwards \\
$0.05 \% \mathrm{WHC}$ & All of its leaves had dried up and two out of the five leaves where folded \\
$0.1 \% \mathrm{WHC}$ & Leaves were necrotic (dried up) \\
$0.5 \% \mathrm{WHC}$ & Leaves were brown and the whole seedling was dry \\
$1 \% \mathrm{WHC}$ & Leaves were necrotic with one out of its five leaves twisted \\
$5 \% \mathrm{WHC}$ & Signs of foliar necrosis. An additional leaf showed partial necrosis \\
Control & Leaves were fresh and green, only two leaves showed signs of foliar scorching
\end{tabular}

Note: WHC - water holding capacity. 
sustainable irrigation practices. The findings from this study suggest that drought produces variable growth and developmental response in E. guineensis seedlings such as a decrease in height, leaf area, number of leaves and roots for most of the seedlings exposed to drought condition. An important caveat to the findings reported here is a potential birch effect resulting from the drying of experimental soil. However, many oil palm cultivation regions around the world are currently having prolonged dry seasons without rain.

\section{ACKNOWLEDGEMENT}

The authors would like to thank the Director-General of MPOB for permission to publish this article.

\section{REFERENCES}

Al-Amin, A Q; Leal, W; De la Trinxeria, J M; Jaafar, A H and Ghani, Z A (2011). Assessing the impacts of climate change in the Malaysian agriculture sector and its influences in investment decision. MiddleEast J. Scientific Research, 7(2): 225-234.

Ashraf, M and Harris, P J C (2013). Photosynthesis under stressful environments: An overview. Photosynthetica, 51(20): 163-190.

Caliman, J P and Southworth, A (1998). Effect of drought and haze on the performance of oil palm. 1998 International Oil Palm Conference Commodity of the Past, Today and the Future. 2325 September 1998. Bali, Indonesia. Indonesia Oil Palm Research Institute (IOPRI) and Indonesia Palm Oil Producers Association (GAPKI). $40 \mathrm{pp}$.

Carr, M K V (2011). The water relations and irrigation requirements of oil palm (Elaeis guineensis): A review. Expl. Agric. 47(4): 629-652.

Corley, R H V; Rao, V; Palat, T and Praiwan, T (2018). Breeding for drought tolerance in oil palm. J. Oil Palm Res., 30(1): 26-35.

Delperee, C; Kinet, J M and Lutts, S (2003). Low irradiance modifies the effect of water stress on survival and growth-related parameters during the early developmental stages of buckwheat (Fagopyrum esculentum). Physiologia Plantarum J., 119(20): 211-220.

Fahramand, M; Mahmoody, M; Keykha, A; Noori, $\mathrm{M}$ and Rigi, A (2014). Influence of abiotic stress on proline, photosynthetic enzymes and growth. Int. Res. J. Applied and Basic Science, 8: 257-265.
FAO (2002). Small-scale palm oil processing in Africa. Agricultural Services Bulletin. Food and Agriculture Organisation of the United Nations (FAO). http:/ / www.fao.org/3/y4355e/y4355e03. htm

Gupta, N K; Gupta, S and Kumar, A. (2001). Effect of water stress on physiological attributes and their relationship with growth and yield of wheat cultivars at different stages. J. Agronomy and Crop Science, 186(1): 55-62.

Hartley, C W S (1988). The Oil Palm. Tropical Agriculture Series. Longman. 59 pp.

Henson, I E and Harun, M H (2007). Short-term responses of oil palm to an interrupted dry season in North Kedah, Malaysia. J. Oil Palm Res., 19: 364372.

Hormaza, P; Fuquen, E M and Romero, H M (2012). Phenology of oil palm interspecific hybrid Elaeis oleifera x Elaeis guineensis. Scientia Agricola, 69(4): DOI. 10.1590/S0103-90162012000400007.

Iankova, K; Hassan, A and L'Abbe, R (2016). Indigenous People and Economic Development: An International Perspective. Routleedge. 344 pp.

Ikhajiagbe, B and Anoliefo, G O (2011). Impact of substrate amendment on the polyaromatic hydrocarbon contents of a five month old waste engine oil polluted soil. African J. Environmental Science and Technology, 5(10): 769-777.

Ikhajiagbe, B; Anoliefo, G O; Olise, F O; Rackelmann, F; Sommer, M and Adekunle, I J (2020). Major phosphorus in soils is unavailable, yet critical for plant development. Notulae Scientia Biologicae, 12(3): 500-535.

Jafaar, H Z E and Ibrahim, M H (2012). Photosynthesis and quantum yield of oil palm seedlings to elevated carbon dioxide. Advances in Photosynthesis - Fundamental Aspects (Najafpour, M ed.). IntechOpen, United Kingdom. p. 321-334.

Kabiri, R (2010). Effect of salicylic acid to reduce the oxidative stress caused by drought in the hydroponic cultivation of Nigella sativa (Nigella sativa). Masters thesis. Shahid Bahonar University of Kerman, Iran. $132 \mathrm{pp}$.

Kafi, $\mathrm{M}$ and Mahdavi-Damghany, M A (1999). Mechanisms of resistance of plants to environmental stresses (Translation). University of Mashhad, Iran. 84 pp. 
Kavar, T; Maras, M; Kidric, M; Sustar-Vozlic, J and Meglic, V (2007) Identification of genes involved in the response of leaves of Phaseolus vulgaris to drought stress. Molecular Breeding, 21(5): 159-172.

Lai, C H; Settinayake, A R H; Yeo, W S; Lau S W and Jong, T K (2019). Crop nutrients review and the impact of fertilizer on the plantation in Malaysia: A mini review. Communications in Soil Science and Plant Analysis, 50(17): 2089-2105.

Mshelmbula, B P; Okooboh, G; Mensah, J K; Ikhajiagbe, B and Zakariya, R (2015). The effects of indole-3-acetic acid (IAA) on the growth and yield of sesame (Sesamum indicum L.) under drought conditions. Int. J. Science and Knowledge, 4(1): 60-65.

Neilson, E H; Edwards, A M; Blomstedt, C K; Berger, B; Møller, B L and Gleadow, R M (2015). Utilization of a high-throughput shoot imaging system to examine the dynamic phenotypic responses of a C4 cereal crop plant to nitrogen and water deficiency over time. J. Experimental Botany, 66(41): 1817-1832.

Okolo, C C; Okolo, E C; Nnadi, A I; Obikwelu, F E; Obalum, S E and Igwe, C A (2019). The oil palm (Elaeis guineensis Jacq.): Nature's ecological endowment to eastern Nigeria. J. Tropical Agriculture, Food, Environment and Extension, 18(3): 48-57.

Ogwu, M C (2018). Effects of Indole-3-Acetic Acid on growth parameters of Citrullus lanatus (Thunberg) Matsum and Nakai. Momona Ethiopian J. Science, 10(1): 109-125. http://dx.doi.org/10.4314/ mejs.v10i1.8

Ogwu, M C (2019). Towards sustainable development in Africa: The Challenge of urbanization and climate change adaptation. The Geography of Climate Change Adaptation in Urban Africa (Cobbinah, P B and Addaney, M eds.). Springer Nature, Switzerland. p. 29-55. http: / / doi. org / 10.1007/978-3-030-04873-0_2

Ogwu, M C; Aiwansoba, R O and Osawaru, M E (2015). Effects of indole-3-acetic acid on germination in lead polluted petri dish of Citrullus lanatus (Thunberg) Matsumura and Nakai, Cucurbitaceae. Aceh Int. J. Science and Technology, 4(3): 107-113. http: / / doi.org/10.13170/ aijst.4.3.3021

Ogwu, M C; Osawaru, M E and Chime, A O (2014). Comparative assessment of plant diversity and utilization patterns of tropical home gardens in Edo State, Nigeria. Scientia Africana, 13(2): 146-162.
Osawaru, M E; Ogwu, M C and Ahana, C M (2014a). Study of the distinctiveness of two genera of Cocoyam (Colocasia [Schott] and Xanthosoma [Schott]) using SDS - PAGE. Nigerian Society for Experimental Biology J., 14(3): 168-179.

Osawaru, M E; Ogwu, M C and Omologbe, J (2014b). Characterization of three Okra [Abelmoschus (L.)] Accessions using morphology and SDS-PAGE for the basis of conservation. Egyptian Academic J. Biological Sciences, 5(1): 55-65.

Osawaru, M E; Ogwu, M C; Ogbeifun, N S and Chime, A O (2013). Microflora diversity of the phylloplane of wild Okra (Corchorus olitorius L. Jute). Bayero J. Pure and Applied Sciences, 6(2): 136142.

Parker, W C and Pallardy, S G (1985). Genotypic variation in tissue water relations of leaves and roots of black walnut (Juglans nigra) seedlings. Physiologia Plantarum J., 64(1): 105-110.

Poku, K (2002). Oil palm. FAO Agricultural Services Bulletin No. 148. Food and Agriculture Organization of the United Nations (FAO). Rome, Italy.

Puértolas, J; Larsen, E K; Davies, W J and Dodd I C (2017). Applying 'drought' to potted plants by maintaining suboptimal soil moisture improves plant water relations. J. Experimental Botany, 68(9): 2413-2424.

Russell, R; Peterson, M and Lima, N (2017). Climate change affecting oil palm agronomy and oil palm cultivation increasing climate change, require amelioration. Ecology and Evolution, 8(1): 452-461.

Safitri, L; Hermantoro, H; Purboseno, S; Kautsar, V; Saptomo, S K and Kurniawan, A (2019). Water footprint and crop usage of oil palm (Elaeis guineensis) in central Kalimantan: Environmental sustainability indicators for different crop age and soil conditions. Water, 11: 35. DOI. 10.3390/ w11010035

Silva, P A; Cosme, V S; Rodrigues, K C B; Detmann, K S C; Leao, F M; Cunha, R L; Buselli, R A F; da Matta, F M and Pinheiro, H A (2018). Drought tolerance in two oil palm hybrids as related to adjustments in carbon metabolism and vegetative growth. Acta Physiologiae Plantaum, 39: 58. DOI 10.1007 / s11738-017-2354-4

Smith, G R (1974). Rapid determination of nitratenitrogen in soil and plants with the nitrate electrode. Electrochemistry, 8(7): 503-508. 
Woittiez, L S; van Wijk, M T; Slingerland, M; van Noordwijk, M and Giller, K E (2017). Yield gap in oil palm: A quantitative review of contributing factors. European J. Agronomy, 83: 57-77.

Zain, N A M; Ismail, M R; Mahmood, M; Puteh, A and Ibrahim, M H (2014). Alleviation of water stress effects on MR220 rice by application of periodical water stress and potassium fertilization. Molecules, 19: 1795-1819.
Zgallai, H; Steppe, K and Lemeur, R (2006). Effects of different levels of water stress on leaf water potential, stomata resistance, protein and chlorophyll content and certain anti-oxidative enzymes in tomato plants. J. Integrative Plant Biology, 48(22): 679-685.

Zlatev, Z and Lindon, F C (2012). An overview on drought induced changes in plant growth, water relations and photosynthesis. Emirates J. Food and Agriculture, 24(1): 57-72. 